\title{
Formulation and Optimization of Dicyclomine HCl mouth melt tablets by central composite design
}

\author{
E. Bhargav*, C. Suryaprakash Reddy, M. V. Jyothi, T. Srikanth, S. Sravani, M. Suresh Krishna, \\ T. Silpa, K. G. Murali, A. Sudha Rani \\ Department of Pharmaceutics, Raghavendra Institute of Pharmaceutical education and Research, K.R. Palli cross, near S.K University, Anantapur, India.
}

\begin{tabular}{|c|c|}
\hline ARTICLE INFO & ABSTRACT \\
\hline Article history: & Dicyclomine $\mathrm{HCl}$ mouth melt tablets were formulated and optimized by Central composite design. \\
\hline Received on: 04/06/2017 & Method: Independent variables (concentrations of Dehydrated Banana powder DBP, $\mathrm{X}_{1}$ and Orange peel pectin \\
\hline Accepted on: 06/08/2017 & powder OPP, $\mathrm{X}_{2}$ ) and dependent variables (In vitro dispersion time, $\mathrm{Y}_{1}$ and percentage drug release, $\mathrm{Y}_{2}$ ) were \\
\hline Available online: $30 / 09 / 2017$ & selected based on literature search. The model was found to be nonlinear and the curvature effect was \\
\hline \multirow{7}{*}{$\begin{array}{l}\text { Key words: } \\
\text { Super disintegrants, Central } \\
\text { composite design, Contour } \\
\text { plots. }\end{array}$} & $\begin{array}{l}\text { S1gnificant. Therefore study resorted to composite design for optimization. } \\
\text { Results: DSC studies indicated drug and excipients were compatible. Precompression parameters indicated }\end{array}$ \\
\hline & fairly good flow properties. By direct compression method all the tablets were formulated, evaluated for \\
\hline & postcompression parameters and were found to be within specified limits. Drug release from all the formulations \\
\hline & followed first order. Contour plots were used to decide most economical batch which were in desired range. The \\
\hline & $\begin{array}{l}\text { statistical model is mathematically valid as the experimental values and predicted values were relatively close to } \\
\text { each other and suggested that the statistical model is mathematically valid. }\end{array}$ \\
\hline & Conclusion: The results demonstrated the effectiveness of the proposed design for development of Dicyclomine \\
\hline & $\mathrm{HCl}$ Mouth melt tablets with optimized properties. \\
\hline
\end{tabular}

\section{INTRODUCTION}

The oral route is the best way for administration of drugs. Due to its ease of administration, manufacturing, precise dosing, stability and tamper proof tablet is one of the most chosen dosage form administered orally when compared with oral liquids (CheinYie, 2011). Paediatrics and geriatric patients, due to the physiological changes shows difficulty in swallowing which is a common problem associated with these groups. Improvement of a Mouth melt tablet a novel type of solid dosage form may reduce difficulty in swallowing, since they show faster disintegration and melts rapidly in saliva without

\footnotetext{
* Corresponding Author

E Bhargav, Department of Pharmaceutics Raghavendra Institute of Pharmaceutical education and Research K.R. Palli cross, near S.K University Anantapur Andhra Pradesh, India.

Email ID: bhargaveranti @ yahoo.com; Contact No. +919052510092
}

the need of drinking water where the tablet disperses rapidly in the mouth before it is swallowed (Bi et al., 1996; Bi et al., 1999). Orodispersible tablets, fast dissolving tablets, melt-in-mouth tablets, rapid melts, porous tablets and quick dissolving tablets were categorized under mouth dissolving tablets (Sreenivas et al., 2005). In the treatment of smooth muscle spasm of the gastrointestinal tract an antispasmodic drug Dicyclomine $\mathrm{HCl}$ is widely used. It is rapidly absorbed orally but undergoes extensive first pass Metabolism. So the present study aimed at developing mouth-melt tablets of Dicyclomine $\mathrm{HCl}$ using natural superdisintegrants to reduce first pass metabolism and to increase the bioavailability of drug which may show faster onset of action in relieving spasms of the gastrointestinal tract as compared to conventional tablet dosage form. Superdisintegrants by water absorption and swelling in the formulations exhibits faster disintegration, promotes wettability \& dispersibility through increased wetted surface by providing faster disintegration and dissolution. 
Based on a number of factors, their levels, and possible interactions Design of experiment (DoE) tool is used in R\&D to formulate drugs of quality with fewer trials at low cost (Cavazzuti, 2013). Combination of factorial design or fractional factorial design and the star design, Central Composite design is developed by Box and Wilson. The model is validated using ANOVA. Combination and interaction of independent variables (e.g. material attributes) and dependent variables utilises design space to assure quality as per ICH Q8 (R2). In the present study, Dicyclomine $\mathrm{HCl}$ mouth melt tablets were formulated and optimized by central composite design to study the effect of independent variables (natural superdisintegrants) on in vitro dispersion time and in vitro drug release.

\section{MATERIALS AND METHODS Materials}

Dicyclomine $\mathrm{HCl}$ (Indoco Remedies Ltd. Navi Mumbai, India), Aspartame, Mannitol, Talc, Magnesium stearate and microcrystalline cellulose were procured from S.D. Fine Chemicals, Mumbai, India.

\section{Methods}

\section{Compatibility studies}

\section{Differential Scanning Calorimeter (DSC)}

Accurately weighed $5 \mathrm{mg}$ of drug alone and passed through the \#60 sieve, transferred to DSC aluminium pan and scanned at $25-210^{\circ} \mathrm{C}$ temperature at heating rate of $10^{\circ} \mathrm{C} / \mathrm{min}$. The same procedure was carried out for optimized formulation also. The thermograms obtained were compared for any interaction with optimized formulation and pure drug alone (Bhargav et al., 2016).

\section{Selection of excipients for formulation development of model drug}

Natural Superdisintegrants as independent variables were selected for formulation development of model drug based on literature search, by experimentation done by authors in previous study (Haranath et al., 2016; Asha Latha et al., 2015) and Preformulation studies.

\section{Preparation of Dehydrated Banana Powder}

Bananas were purchased from local market of Ananthapuramu. Removed the peels and were sliced into pieces. Distilled water was added to remove the water-soluble contents in the pulp. Then preservative, $0.2 \% \mathrm{w} / \mathrm{w}$ methyl paraben was added and the pulp was grinded using domestic mixer. Transferred to hot air oven, dried at $45^{\circ} \mathrm{C}$ for 24 hours and sieved through Sieve No. 80 to get dehydrated Banana powder (Haranath et al., 2016).

\section{Preparation of Orange peel pectin powder}

Ripped oranges were procured obtained from from local market of Anantapuramu. Then peel was removed, washed carefully and driedby placing the peel under shade for $24 \mathrm{~h}$. Then dried in a hot air oven at $60{ }^{\circ} \mathrm{C}$. After drying it was made into pieces and powdered. Then sieved through sieve No. 20. $200 \mathrm{~g}$ of
Peel powder was transferred to a solution of $1 \mathrm{~L}$ water containing 1 $\mathrm{g}$ of citric acid maintained at $\mathrm{pH} 2$. For extraction of pectin, it was subjected to reflux condensation at $70{ }^{\circ} \mathrm{C}$ for $6 \mathrm{~h}$. A cheese cloth bag was taken and the concentrated juice was obtained by pressing hot acid extract and further cooled to $4{ }^{\circ} \mathrm{C}$ followed by precipitation of pectin using ethanol: water $(2: 1 \mathrm{v} / \mathrm{v})$ treatment with continuous stirring for $15 \mathrm{~min}$ and left aside for $2 \mathrm{~h}$. The obtained Pectin coagulate was filtered through cheese cloth, washed with $95 \%$ alcohol and pressed. Further dried at $35-45^{\circ} \mathrm{C}$ to constant weight. The hard pectin cake was ground in domestic mixer and then passed through sieve No.60, for further use stored in desiccators (Asha Latha et al., 2015).

\section{Characterization of Dehydrated banana powder and Orange peel pectin powder}

Physiochemical evaluation like solubility, viscosity, swelling index, Bulk density, tap density, Angle of repose was done for dehydrated banana powder and Orange peel pectin powder (Arun Raj 2013).

In present investigation $2^{2}$ factorial design with 4 replicates were selected for design of experimentation of tablets (Table 1). The model was found to be nonlinear and the curvature effect was significant. Therefore study resorted to central composite design for optimization (Table 2).

Table 1: Experimental design of tablets as per $2^{2}$ Factorial Level.

\begin{tabular}{ccccc}
\hline $\begin{array}{c}\text { Factor } \\
\text { No. }\end{array}$ & Factor & Units & $\begin{array}{c}\text { Low } \\
\text { Level }\end{array}$ & High Level \\
\hline 1 & Dehydrated Banana powder & $\mathrm{mg}$ & $9(-1)$ & $15(+1)$ \\
2 & Orange peel pectin powder & $\mathrm{mg}$ & $12.63(-1)$ & $16.32(+1)$ \\
\hline
\end{tabular}

Table 2: Central composite design layout.

\begin{tabular}{cccc}
\hline $\begin{array}{c}\text { Formulation } \\
\text { code }\end{array}$ & Combinations & DBP $(\mathbf{X 1})(\mathbf{m g})$ & OPP $(\mathbf{X 2})(\mathbf{m g})$ \\
\hline F1 & I & $9(-1)$ & $12.63(-1)$ \\
F2 & X1 & $15(+1)$ & $12.63(-1)$ \\
F3 & X2 & $9(-1)$ & $16.32(+1)$ \\
F4 & X1X2 & $15(+1)$ & $16.32(+1)$ \\
F5 & Mid-point & $12(0)$ & $14.475(0)$ \\
F6 & X1At-2L & $6(-2)$ & $14.475(0)$ \\
F7 & X1At+2L & $18(+2)$ & $14.475(0)$ \\
F8 & X1At-2L & $12(0)$ & $10.785(-2)$ \\
F9 & X1At+2L & $12(0)$ & $18.165(+2)$ \\
\hline
\end{tabular}

\section{Pre-compression parameters}

Bulk density (BD)

By keeping the $100 \mathrm{ml}$ graduated cylinder in a slanting position accurately weighed blend sample was transferred into it. Initial volume and weight were noted. Bulk density was calculated by the ratio of weight of the sample to the volume it occupied (Milind et al., 2010).

\section{Tapped density (TD)}

Accurately weighed blend sample was transferred into $100 \mathrm{ml}$ measuring cylinder was used for determining tapped density (Electrolab Tapped Density Apparatus). Initial volume $\left(\mathrm{V}_{0}\right)$ of the cylinder was noted and then the cylinder was tapped for 10 times and the volume was measured. Further additional 500 
tapings were made and the volume was noted. Continue the tapings to 1250 if the difference between the volume measured after 10 and 500 tapings was more than $2 \mathrm{ml}$ (Milind et al., 2010).

\section{Compressibility index (CI)}

Compressibility index (CI) is direct measurement of potential powder arch or the bridge strength and stability. It was calculated according to the equation given below (Milind et al., 2010).

$$
C I=\left(T D-\frac{B D}{T D}\right) * 100
$$

\section{Hausner ratio}

Flow of powder determined by Hausner ratio and determined using following formula (Milind et al., 2010)

Hausner ratio $=$ Tapped density $/$ Bulk density

\section{Angle of repose}

Funnel method was used to determine angle of repose (a). The blend was poured through a funnel that can be raised vertically to a maximum cone height (h). Angle of repose was calculated by measuring the radius of the heap (r) (Milind et al., 2010).

$$
\mathrm{a}=\tan ^{-1}(\mathrm{~h} / \mathrm{r})
$$

Blend of drug and excipients were mixed and convex faced tablets were compressed using $7 \mathrm{~mm}$ punch on "B" Tooling Rotary Tablet compression Machine.

\section{Formulation of Dicyclomine blend by dry mixing}

Direct compression was used for the formulation of Dicyclomine Mouth melt tablets (Table 3). All the required ingredients were weighed and sieved through mesh no. 60 separately. By using mortar and pestle drug, Mannitol and microcrystalline cellulose were mixed uniformly with gentle trituration to get a uniform mixture. Required weighed quantities of superdisintegrants and aspartame were taken for each specified formulation and mixed to the above mixture. Finally lubricated with magnesium stearate and talc.

\section{Physical characterization of the tablets Weight variation}

20 tablets were selected randomly; the weight of individual tablet and the average weight of the tablets were noted (Pabari et al., 2012).

\section{Tablet thickness}

Twenty tablets were taken and their thickness was recorded using Vernier caliper scale (Pabari et al., 2012).

\section{Hardness}

Monsanto hardness tester was used to determine hardness of five tablets was from each formulation. The tablet was held between anvil and spindle. By applying constant force the knob was rotated until the tablet fractured (Pabari et al., 2012).

\section{Friability}

Roche friabilator was used to determine friability, rotated at $25 \mathrm{rpm} / \mathrm{min}$ for $4 \mathrm{~min}$. Initial weight of 20 tablets was noted and loss in weight (\%) was calculated (Pabari et al., 2012).

$$
\begin{aligned}
& \text { Friability }=(\mathrm{W} 1-\mathrm{W} 2) / \mathrm{W} 1 \times 100 \\
& \text { Weight of } 40 \text { Tablets }=\mathrm{W} 1, \\
& \text { Weight of } 40 \text { Tablets after friability }=\mathrm{W} 2
\end{aligned}
$$

\section{Drug content}

Twenty tablets were weighed individually and powdered from each formulation. To $10 \mathrm{ml}$ of methanol equivalent weight of $20 \mathrm{mg}$ of Dicyclomine $\mathrm{HCl}$ was added and volume was adjusted to $100 \mathrm{ml}$ with $\mathrm{pH} 6.8$ buffer. $1 \mathrm{ml}$ was taken from the above prepared solution and made up to $100 \mathrm{ml}$ with pH6.8 buffer then analyzed at $217 \mathrm{~nm}$ by UV-visible spectrophotometer (Pathikkumar et al., 2013).

\section{In vitro disintegration time}

The test was conducted for six tablets of each formulation at $37^{\circ} \mathrm{C} \pm 0.5^{\circ} \mathrm{C}$ using disintegration apparatus. Distilled water was used as disintegration medium. A tablet was placed in each of six tubes of the apparatus and one disc was

\begin{tabular}{|c|c|c|c|c|c|c|c|c|c|}
\hline Ingredients & $\begin{array}{c}\text { F1 } \\
(\mathbf{m g})\end{array}$ & $\begin{array}{c}\text { F2 } \\
(\mathbf{m g})\end{array}$ & $\begin{array}{c}\text { F3 } \\
(\mathbf{m g})\end{array}$ & $\begin{array}{c}\mathbf{F 4} \\
(\mathrm{mg})\end{array}$ & $\begin{array}{c}\mathbf{F 5} \\
(\mathrm{mg})\end{array}$ & $\begin{array}{c}\text { F6 } \\
\text { (mg) }\end{array}$ & $\begin{array}{c}\text { F7 } \\
(\mathbf{m g})\end{array}$ & $\begin{array}{c}\mathbf{F 8} \\
(\mathbf{m g})\end{array}$ & $\begin{array}{c}\text { F9 } \\
\text { (mg) }\end{array}$ \\
\hline Dicyclomine HCL & 20 & 20 & 20 & 20 & 20 & 20 & 20 & 20 & 20 \\
\hline Dehydrated Banana powder & 9.0 & 15 & 9.0 & 15 & 12 & 6.0 & 18 & 12 & 12 \\
\hline Orange peel pectin powder & 12.63 & 12.63 & 16.32 & 16.32 & 14.47 & 14.47 & 14.47 & 10.78 & 18.16 \\
\hline Mannitol & 170.5 & 170.5 & 170.5 & 170.5 & 170.5 & 170.5 & 170.5 & 170.5 & 170.5 \\
\hline Micro crystalline cellulose & 79.87 & 73.87 & 76.18 & 70.10 & 75.03 & 81.03 & 69.03 & 78.72 & 71.34 \\
\hline Aspartame & 6 & 6 & 6 & 6 & 6 & 6 & 6 & 6 & 6 \\
\hline Magnesium stearate & 1.0 & 1.0 & 1.0 & 1.0 & 1.0 & 1.0 & 1.0 & 1.0 & 1.0 \\
\hline Talc & 1.0 & 1.0 & 1.0 & 1.0 & 1.0 & 1.0 & 1.0 & 1.0 & 1.0 \\
\hline Total weight (mg) & 300 & 300 & 300 & 300 & 300 & 300 & 300 & 300 & 300 \\
\hline
\end{tabular}
added to each tube, complete disintegration of the tablet with no mass remaining in the apparatus was measured in seconds (Pathikkumar et al., 2013).

Table 3: Formulation of Dicyclomine $\mathrm{HCl}$ mouth melt tablets 


\section{Wetting time}

Five circular tissue papers of $10 \mathrm{~cm}$ diameter are placed in a Petri dish. To Ten millimetres of water, a water soluble dye Eosin was added and poured the prepared dye solution into Petri dish. A tablet is carefully placed on the surface of the tissue paper. Then wetting was noted, as the time required for water to reach upper surface of the tablet (Asha Latha et al., 2015).

\section{Water absorption ratio}

To a petri plate containing $6 \mathrm{ml}$ of distilled water a piece of folded tissue paper was placed in to it. The time for complete wetting of the tablet was measured in seconds by placing pre weighed tablet on the paper. After wetting the tablet weight was noted. Water absorption ratio was calculated using the formula, (Milind et al., 2010)

$$
\mathrm{R}=(\mathrm{Wa}-\mathrm{Wb}) / \mathrm{Wa} \mathrm{X} 100
$$

Where $\mathrm{R}=$ Water absorption ratio, $\mathrm{Wa}=$ Weight of tablet after wetting, $\mathrm{Wb}=$ Weight of tablet before wetting.

\section{In vitro dispersion time}

To a beaker with $10 \mathrm{ml}$ of phosphate buffer solution $(\mathrm{pH}$ 6.8) maintained at $37 \pm 0.5^{\circ} \mathrm{C}$ a tablet was added and measured the time required for its complete dispersion (Milind et al., 2010).

\section{In vitro drug release}

USP 24 method Type II apparatus, paddle (Electro lab) at 50 RPM was used for determining drug release from Dicyclomine $\mathrm{HCl}$ tablets. $900 \mathrm{ml}$ of phosphate buffer ( $\mathrm{pH}$ 6.8) maintained at 37 $\pm 0.5^{\circ} \mathrm{C}$ used as dissolution medium. At specified time intervals Five milliliters of the sample was withdrawn from the cylindrical vessel and replaced with $5 \mathrm{ml}$ of fresh media maintained at $37 \pm 0.5^{\circ} \mathrm{C}$. Whatman filter paper (no.41) was used for filtration of samples then suitably suitably diluted with phosphate buffer ( $\mathrm{pH} \mathrm{6.8)}$ and analyzed at $217 \mathrm{~nm}$ using a
UV-Visible spectrophotometer (Shimadzu) (Pathikkumar et al., 2013).

\section{Statistical analysis and Optimization}

Data obtained from all mouth melt tablet formulations were analyzed using Sigma Tech software (version 3.1) to generate the study design. Based on several statistical parameters provided by Sigma Tech software best-fit model was selected. Significant effects of independent variables on response regression coefficients were identified by Analysis of variance (ANOVA). Contour plots, a graphical optimization technique was used to study significant effected responses between factors \& responses and to generate the new formulations with desired responses. The generated formulation (predict values) was evaluated for In vitro dispersion time and dissolution studies to verify closeness between predicted and experimental values. The predicted and experimental values were calculated for relative errors (\%) (Reddy et al., 2016; Bansod et al., 2014).

\section{Stability studies}

Stability of optimized formulation was carried out at $40^{\circ}$ $\mathrm{C} \pm 2{ }^{\circ} \mathrm{C} / 75 \% \pm 5 \% \mathrm{RH}$ for 3 months which was filled in HDPE containers. The optimized formulation was evaluated for in vitro dispersion time and in vitro drug release for 3 months respectively (Prusty et al., 2016).

\section{RESULTS AND DISCUSSION}

\section{Compatibility studies \\ Differential Scanning Calorimeter (DSC)}

DSC thermographs revealed that the melting point of the pure drug is $180.27^{\circ} \mathrm{C}$ and that of the drug in the formulation is $144.51^{\circ} \mathrm{C}$. Presence of Dehydrated Banana powder and Orange peel pectin powder (Super disintegrants) reduced the melting point of Dicyclomine $\mathrm{Hcl}$ (pure drug) in optimized formulation and hence solubility is enhanced, as illustrated in Figure $1 \& 2$.

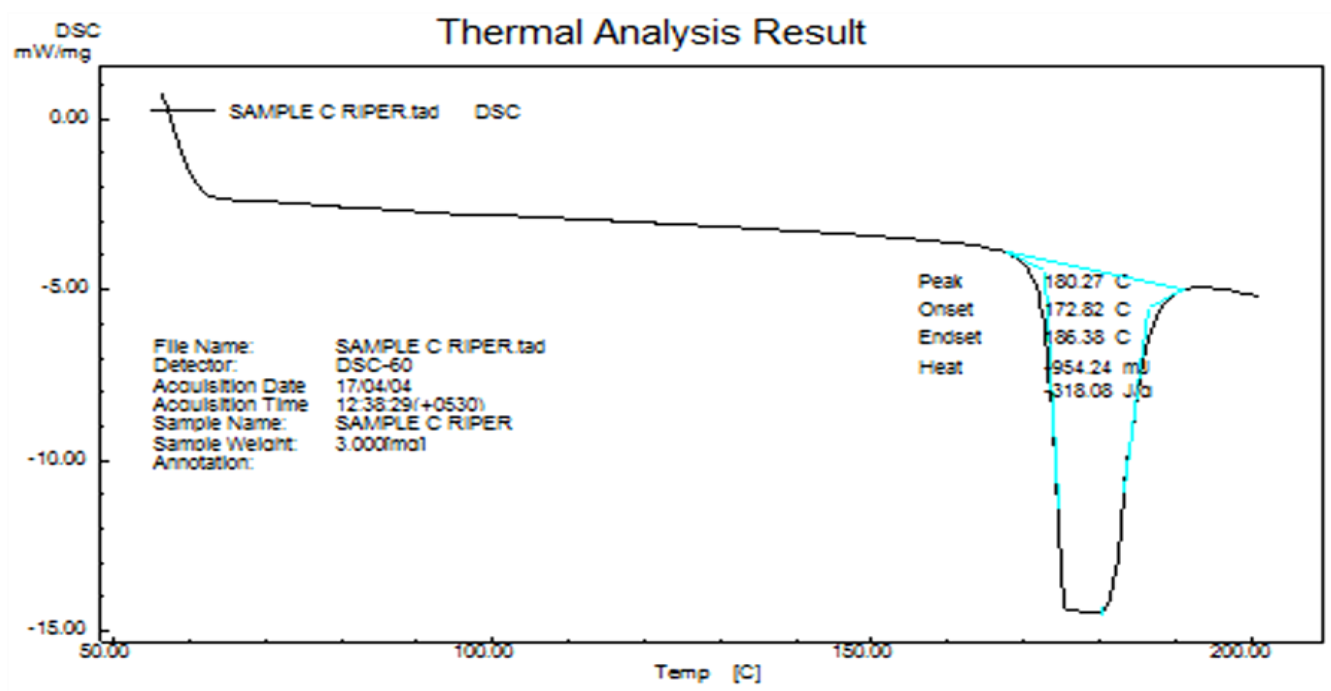

Fig. 1: DSC thermogram of Dicyclomine $\mathrm{HCl}$ pure drug. 


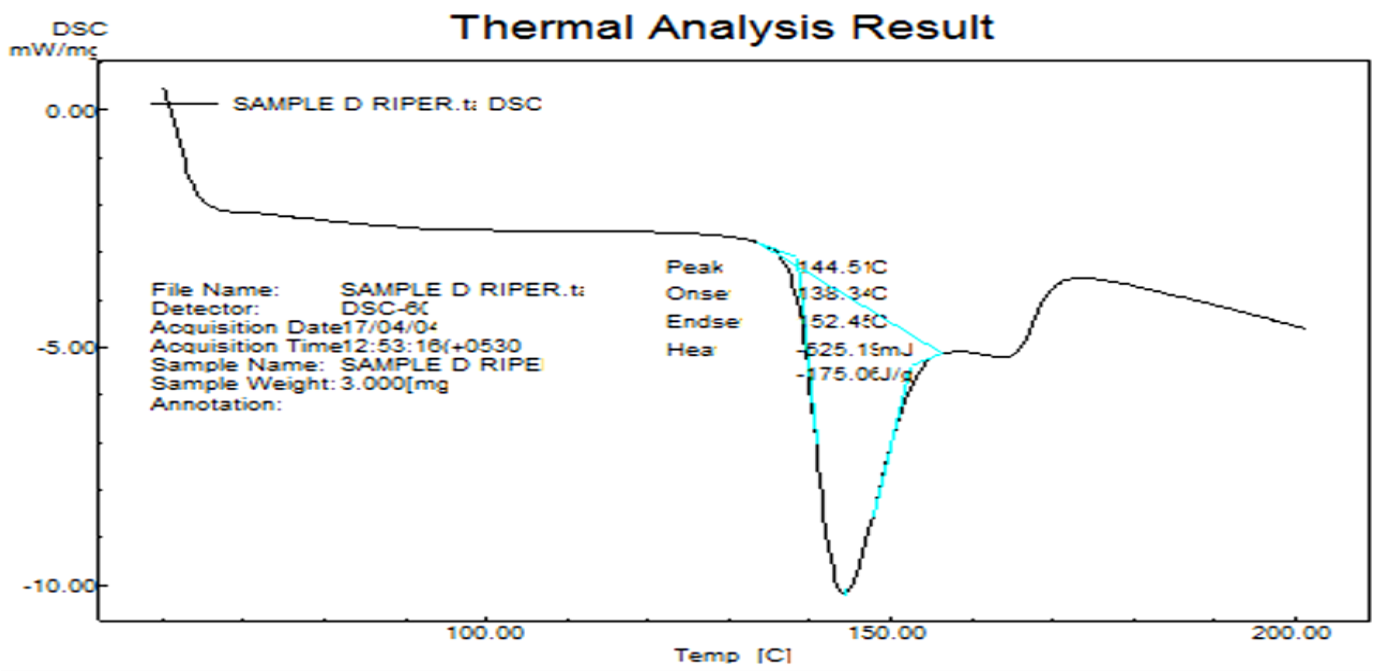

Fig. 2: DSC thermogram of optimized formulation.

Table 4: Evaluation of Pre compression parameters.

\begin{tabular}{|c|c|c|c|c|c|}
\hline Formulation code & $\begin{array}{c}\text { Bulk density } \\
(\mathrm{g} / \mathrm{cm} 3)\end{array}$ & $\begin{array}{c}\text { Tapped density } \\
(\mathrm{g} / \mathrm{cm} 3)\end{array}$ & $\begin{array}{c}\text { Compressibility } \\
\text { Index }(\%)\end{array}$ & Hausner's ratio & Angle of repose \\
\hline F1 & $0.320 \pm 0.041$ & $0.408 \pm 0.0 .35$ & 21.56 & 1.27 & $28^{\circ} .32 \pm 0.041$ \\
\hline F2 & $0.335 \pm 0.020$ & $0.390 \pm 0.038$ & 14.10 & 1.16 & $27^{\circ} .51 \pm 0.020$ \\
\hline F3 & $0.314 \pm 0.021$ & $0.404 \pm 0.026$ & 22.27 & 1.28 & $35^{\circ} .63 \pm 0.021$ \\
\hline F4 & $0.342 \pm 0.043$ & $0.429 \pm 0.060$ & 20.27 & 1.25 & $34^{\circ} .03 \pm 0.043$ \\
\hline F5 & $0.334 \pm 0.026$ & $0.406 \pm 0.023$ & 17.73 & 1.21 & $30^{\circ} .95 \pm 0.026$ \\
\hline F6 & $0.317 \pm 0.022$ & $0.401 \pm 0.014$ & 20.94 & 1.26 & $31^{\circ} .39 \pm 0.035$ \\
\hline F7 & $0.342 \pm 0.024$ & $0.433 \pm 0.075$ & 21.01 & 1.26 & $28^{\circ} .25 \pm 0.047$ \\
\hline F8 & $0.344 \pm 0.044$ & $0.403 \pm 0.013$ & 14.64 & 1.17 & $29^{\circ} .21 \pm 0.026$ \\
\hline F9 & $0.356 \pm 0.029$ & $0.427 \pm 0.028$ & 16.62 & 1.19 & $33^{\circ} .01 \pm 0.031$ \\
\hline
\end{tabular}

All values are expressed as mean \pm standard deviation $(\mathrm{n}=3)$.

Table 5: Evaluation of Dicyclomine $\mathrm{HCl}$ Mouth melt tablets -1 .

\begin{tabular}{ccccc}
\hline Formulation code & $\begin{array}{c}\text { Average weight } \\
(\mathbf{m g}) *\end{array}$ & $\begin{array}{c}\text { Thickness } \\
(\mathbf{m m}) *\end{array}$ & $\begin{array}{c}\text { Hardness } \\
(\mathbf{k g} / \mathbf{c m} 2)^{* *}\end{array}$ & $\begin{array}{c}\text { Friability } \\
(\mathbf{\%}) *\end{array}$ \\
\hline F1 & $299 \pm 2.6$ & $4.10 \pm 0.090$ & $2.5 \pm 0.110$ & $0.54 \pm 0.054$ \\
F2 & $300 \pm 1.6$ & $4.18 \pm 0.023$ & $2.3 \pm 0.108$ & $0.23 \pm 0.112$ \\
F3 & $300 \pm 1.8$ & $4.19 \pm 0.518$ & $2.6 \pm 0.648$ & $0.44 \pm 0.198$ \\
F4 & $300 \pm 1.3$ & $4.21 \pm 0.603$ & $2.5 \pm 0.751$ & $0.21 \pm 1.163$ \\
F5 & $300 \pm 1.1$ & $4.16 \pm 0.263$ & $2.7 \pm 0.253$ & $0.46 \pm 0.682$ \\
F6 & $301 \pm 0.8$ & $4.13 \pm 0.648$ & $2.7 \pm 0.612$ & $0.33 \pm 0.263$ \\
F7 & $300 \pm 0.7$ & $4.16 \pm 0.733$ & $2.4 \pm 0.115$ & $0.24 \pm 0.376$ \\
F8 & $300 \pm 2.7$ & $4.18 \pm 0.756$ & $2.3 \pm 0.130$ & $0.41 \pm 0.358$ \\
F9 & $299 \pm 1.2$ & $4.10 \pm 0.758$ & $2.5 \pm 0.786$ & $0.43 \pm 0.421$ \\
\hline
\end{tabular}

All values are expressed as mean \pm standard deviation $\left(n=20^{*}, n=5^{* *}\right)$.

\section{Characterization of Dehydrated banana powder and Orange peel pectin powder}

Banana powder and orange powder were found to be soluble in water. An angle of repose found to be in the required range, $35.12 \& 34.48$ indicated a better flow property for banana powder and orange powder respectively. Angle of repose has been used to characterize the flow properties of powders, it also related to inter particulate friction or resistance to movement between particles.

\section{Precompression parameters}

The prepared dry blend for all formulations indicated good free-flowing property. Compressibility index (CI) and
Hausners ratio was found to be in the range of $14.10 \%$ to $22.17 \%$ and range of 1.16 to 1.29 respectively, as shown in table 4 .

\section{Evaluation of compressed tablets}

All the compressed tablets were evaluated for weight variation, thickness, friability hardness which were in compliance with pharmacopoeial (I.P) standards (Table 5). The percentage drug content of all the compressed tablets found to be in acceptable limits. The formulated and compressed tablets disintegrated within 25-90 Seconds. It was observed that increase in concentration of Dehydrated banana powder decreased disintegration time due to gel formation by its rapid capillary activity and pronounced hydration, the results are in consistent 
Table 6: Evaluation of Dicyclomine $\mathrm{HCl}$ Mouth melt tablets-2.

\begin{tabular}{ccccc}
\hline $\begin{array}{c}\text { Formulation } \\
\text { code }\end{array}$ & $\begin{array}{c}\text { Drug content } \\
(\boldsymbol{\%}) *\end{array}$ & Disintegration time (sec)*** & Wetting time (sec)**** & Water absorption ratio(\%)**** \\
\hline F1 & $99.37 \pm 0.24$ & $40 \pm 0.31$ & $46 \pm 0.78$ & $92.48 \pm 0.19$ \\
F2 & $99.03 \pm 0.77$ & $28 \pm 0.65$ & $35 \pm 0.25$ & $96.3 \pm 0.132$ \\
F3 & $97.31 \pm 0.31$ & $48 \pm 0.28$ & $62 \pm 0.55$ & $85.25 \pm 1.05$ \\
F4 & $97.45 \pm 0.22$ & $48 \pm 0.37$ & $37 \pm 0.12$ & $81.12 \pm 2.63$ \\
F5 & $98.90 \pm 0.63$ & $40 \pm 0.60$ & $51 \pm 0.33$ & $93.41 \pm 3.12$ \\
F6 & $99.30 \pm 0.34$ & $60 \pm 0.63$ & $72 \pm 1.11$ & $86.1 \pm 0.516$ \\
F7 & $98.36 \pm 0.67$ & $25 \pm 0.68$ & $29 \pm 1.28$ & $88.1 \pm 0.662$ \\
F8 & $98.66 \pm 0.23$ & $90 \pm 0.15$ & $57 \pm 0.87$ & $80.2 \pm 0.343$ \\
F9 & $97.40 \pm 0.71$ & $47 \pm 1.32$ & $49 \pm 0.77$ & $94.23 \pm 3.82$ \\
\hline
\end{tabular}

All values are expressed as mean \pm standard deviation $\left(n=20^{*}, n=6^{* *}, n=5^{* * *}\right)$.

with wetting and water absorption time. Increase in disintegration time of Orange peel pectin due to reduction in solubility and increase in wetting time. The wetting time and water absorption ratio for all the compressed tablets was found to be in the range of $29 \pm 1.28$ to $72 \pm 1.11$ and $80.2 \pm 0.343$ to $98.1 \pm 0.662 \%$. Among all formulations, formulation F7 showed highest water absorption ratio due to its more swelling and water penetration capacity (Table 6).

\section{In vitro Dispersion time $\left(\mathrm{Y}_{1}\right)$}

In vitro Dispersion time for all formulations was found to be $33 \mathrm{sec}-130 \mathrm{sec}$ (Table 7).

\section{Final equation in terms of coded factors} $+2.6 \mathrm{X}_{2}^{2}$

$$
\mathrm{Y}_{1}=82.25-16.0 \mathrm{X}_{1}+1.6667 \mathrm{X}_{2}-24.5 \mathrm{X}_{1} \mathrm{X}_{2}-3.15 \mathrm{X}_{1}^{2}
$$

Final equation in terms of actual factors

$\mathrm{Y}_{1}=82.25-16.0 \mathrm{DBP}+1.6667$ OPP- 24.5 DBP OPP$3.15 \mathrm{DBP}^{2}+2.6 \mathrm{OPP}^{2}$

In vitro dispersion data was analysed and found that $\mathrm{X}_{1}$ was highest with SS ratio $(66.93 \%)$ and a negative sign of the coefficient (-24.5). It indicated that the increase in the amount of $\mathrm{X}_{1}$ decreased the dispersion time. $\mathrm{R}^{2}$ model found to be significant hence this model has been used for predictions. Since the relationship between $\mathrm{Y}_{1}$ Vs $\mathrm{X}$ (Independent variables) is nonlinear as shown by Sigma Tech software, the Central composite design has been applied. Magnitude of the coefficient and the mathematical sign (i.e., positive or negative) given by the polynomial equations were used to draw conclusions on responses. The multiple linear regression analysis revealed that dispersion time decreased with increase in Banana powder, dispersion time increased with increase in Orange peel powder. ANOVA was used to identify significant effect, Coefficient of determination $\mathrm{R}^{2}=$ 0.995. The model was found to be significant at $p<0.05$ since the obtained $F$ value is larger than critical F-value. The critical value of $F$ is 4.95, obtained $F$ value (i.e. 6.59) is larger than critical value and so it can be concluded that obtained $\mathrm{F}$ value is likely to occur by chance with a $p<0.05$ i.e. indicates significance at that level of probability. $\mathrm{R}^{2}$ value of this quadratic model is 0.9128 , found to be greater than 0.70 suggesting that this model is reliable for all CQAs Hence used to establish predictions and contours/design space for developing Robust method.

In vitro drug release $\left(\mathrm{Y}_{2}\right)$

In vitro drug release for all formulations was found to be $83.5 \%-103.3 \%$ sec (Table 7).

Final equation in terms of coded factors

Drug release $\left(\mathrm{Y}_{2}\right)=78.05+2.85 \mathrm{X}_{1}-2.65 \mathrm{X}_{2}+4.425$ $\mathrm{X}_{1} \mathrm{X}_{2}+2.775 \mathrm{X}_{1}^{2}-4.075 \mathrm{X}_{2}^{2}$

Final equation in terms of actual factors

$\mathrm{Y}_{2}=78.05+2.85 \mathrm{DBP}-2.65 \mathrm{OPP}+4.425 \mathrm{DBP} \mathrm{OPP}+$ $2.775 \mathrm{DBP}^{2}-4.075 \mathrm{OPP}^{2}$

In vitro drug release data was analysed and found that interaction of $X_{1}$ was highest with SS ratio (54.44\%) and a positive sign of the coefficient (4.425). It indicated that the increase in the amount of $X_{1}$ increased the drug release. Since the relationship between $\mathrm{Y}_{2}$ Vs $\mathrm{X}$ is nonlinear as shown by Sigma Tech software, the Central composite design has been applied. The multiple linear regression analysis showed that drug release increased with increase in Banana powder, drug release decreased with increase in Orange peel powder. Dehydrated Banana powder due to its rapid capillary activity with faster wetting, highest water absorption time and pronounced hydration with little tendency to gel formation showed faster drug release. All the formulations followed First order model and followed fickian diffusion kinetics. ANOVA was used to identify significant effect, Coefficient of determination $\mathrm{R}^{2}=0.9023$. The model was found to be significant at $p<0.05$ since the obtained $\mathrm{F}$ value is larger than critical $\mathrm{F}$-value. The critical value of $F$ is 4.95 , obtained $F$ value (i.e. 6.59) is larger than critical value and so it can be concluded that obtained $F$ value is likely to occur by chance with a $p<0.05$ i.e. indicates significance at that level of probability. $\mathrm{R}^{2}$ value of this quadratic model is 0.851 , found to be greater than 0.70 suggesting that this model is reliable for all CQAs Hence used to establish predictions and contours/design space for developing Robust method. 
Table 7: Composition and Evaluation of the batches prepared by applying Central composite design.

\begin{tabular}{cccccc}
\hline S. No. & Combination redesigned & $\mathbf{X}_{\mathbf{1}}$ & $\mathbf{X}_{\mathbf{2}}$ & $\mathbf{Y}_{\mathbf{1}}{ }^{*}$ & $\mathbf{Y}_{\mathbf{2}}{ }^{*}$ \\
\hline 1 & $\mathrm{I}$ & 9 & 12.63 & $61 \pm 0.318$ & $98.6 \pm 0.62$ \\
2 & $\mathrm{X} 1$ & 15 & 12.63 & $39 \pm 0.206$ & $99.5 \pm 0.18$ \\
3 & $\mathrm{X} 2$ & 9 & 16.32 & $125 \pm 0.44$ & $87.5 \pm 0.28$ \\
4 & $\mathrm{X} 1 \mathrm{X} 2$ & 15 & 16.32 & $45 \pm 0.88$ & $103.3 \pm 0.67$ \\
5 & Mid point & 12.0 & 14.475 & $93 \pm 0.11$ & $83.5 \pm 0.68$ \\
6 & $\mathrm{X} 1 \mathrm{At}-2 \mathrm{~L}$ & 6 & 14.475 & $130 \pm 028$ & $85.9 \pm 0.34$ \\
7 & $\mathrm{X} 1 \mathrm{At}+2 \mathrm{~L}$ & 18 & 14.475 & $34 \pm 1.120$ & $99.8 \pm 0.53$ \\
8 & $\mathrm{X} 1 \mathrm{At}-2 \mathrm{~L}$ & 12 & 10.785 & $77 \pm 0.991$ & $96.6 \pm 0.87$ \\
9 & $\mathrm{X} 1 \mathrm{At}+2 \mathrm{~L}$ & 12 & 18.165 & $72 \pm 1.24$ & $94.2 \pm 0.38$ \\
\hline
\end{tabular}

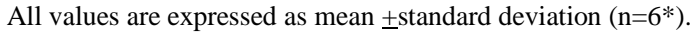

Table 8: Comparison of experimental results with predicted responses of Dicyclomine $\mathrm{HCl}$ Mouth melt tablets formulation.

\begin{tabular}{cccccc}
\hline Ingredient & $\begin{array}{c}\text { Composition } \\
(\mathbf{m g} / \mathbf{t a b})\end{array}$ & Response & Predicted value & $\begin{array}{c}\text { Experimental } \\
\text { value }\end{array}$ & $\begin{array}{c}\text { Standard } \\
\text { error }\end{array}$ \\
\hline DBP & 18 & $\mathrm{Y}_{1}(\mathrm{DT})(\mathrm{sec})$ & 35 & 33 & $1.0 \%$ \\
\hline $\mathrm{OPP}$ & 12.63 & $\mathrm{Y}_{2}(\mathrm{DR})(\%)$ & 100.2 & 99.7 & $0.25 \%$ \\
\hline
\end{tabular}
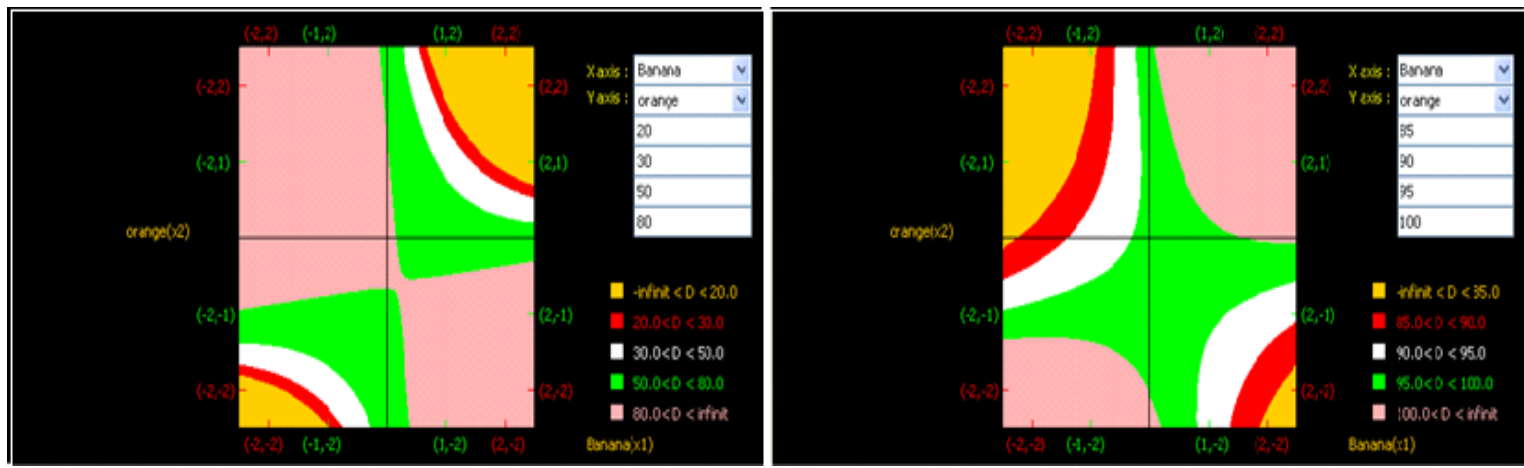

Fig. 3: Contour plots for Dicyclomine $\mathrm{HCl}$ Mouth melt tablets.

\section{Establishing Design space}

Total design space for dispersion time 20-80 min and for drug release $85-100 \%$ (Figure 3). Contour plots permitted the composition Dehydrated banana powder as $18 \mathrm{mg}(+2)$ and orange peel powder $12.63(-1)$. The optimized formulation exhibited closeness between experimental values and theoretical values which confirm validity of the model, the results were shown in table 8.

The optimized formulation showed no significant changes on dependent variables after 3 months and was within specifications.

\section{CONCLUSION}

In this study the statistical optimization technique, central composite design showed that the concentration of natural superdisintegrants have a profound and interactive effect on the dependent variables and showed that the experimental design was successfully applied to optimize the concentration of natural superdisintegrants to formulate mouth melt tablets with desirable properties of low dispersion time and high drug release. It can be concluded that central composite design could be successfully applied for the development of Dicyclomine $\mathrm{HCl}$ Mouth melt tablets with fewer numbers of trials and better quality attributes.
Financial support and sponsorship: Nil.

Conflict of Interests: There are no conflicts of interest.

\section{REFERENCES}

Prusty A, Mishra AK, Gupta BK. Development and evaluation of matrix tablet by taking new chemicals combination of chitosan and eudragit-I 100. J young Pharm. 2016; 8(3): 168-76.

Arun Raj. Comparative evaluation of potato starch and banana powder as disintegrating agents in Aceclofenac tablet formulation. International journal of pharmacy and pharmaceutical sciences 2013; 5(2): 2013.

Asha Latha MA, Padavala S, Bhargavi CH. Formulation and evaluation of fast dissolving tablets of Telmisartan using Natural Superdisintegrants. International journal of innovative drug discovery 2015; 5(1): 25-9.

Bhargav E, Harish P, Haranath C, Suryaprakash C. Formulation and Optimization of gastro retentiveextended-release floating tablets of Tramadol Hydrochloride. Inventi spreading knowledge. 2016;4:1-8.

Bi Y, Sunada H, Danjo K, Otsuka A. Preparation and evaluation of a compressed tablet rapidly disintegrating in the oral cavity. Chem Pharm Bull. 1996; 44(11):2121-7.

Bi Y, Sunada H, Danjo K, Yonezawa Y. Evaluation of rapidly disintegrating tablets prepared by a direct compression method. Drug Dev Ind Pharm. 1999; 25(5):571-81.

Cavazzuti M. Optimization Methods: From Theory to Design scientific and technological aspects. $1^{\text {st }}$ ed: Springer-Verlag Berlin Heidelberg; 2013; 262. 
Reddy C, Reddy YP, Devanna N. Formulation and Optimization of the extended release tablets of Dalfampridine by $2^{3}$ factorial design. Journal of Pharmaceutical and Scientific Innovation. 2016; 5(1):27-37.

CheinYie W. Novel drug delivery systems. $2^{\text {nd }}$ ed. Marcel Dekker. New York: 2011; 139.

Haranath C, Muralidhar P, Harish P, Surya Prakash reddy C. Comparative study of natural and synthetic superdisintegrating agents in the formulation of oral dispersible tablets of Escitalopram-IP. InventiRapid Novel excipients 2016; 3: 1-8.

Milind Wagh P, Chetan Yewale P, Santosh Zate U, Paresh Kothawade I, Ganesh Mahale H. Formulation and evaluation of Fast Dispersible tablets of Aceclofenac using different Superdisintegrants. Int J Pharm PharmSciInt J Pharm Pharm Sci. 2010; 2: 154-7.

Pabari RM, Ramtoola Z. Effect of disintegration mechanism on wetting, water absorption and disintegration time of Orodispersible tablets. J young Pharm. 2012; 4: 157-63.

Pathikkumar J, Maravaniya, Tanvee M. Deshpande, Ramesh Katedeshmukh. Development of Dicyclomine hydrochloride orally disintegrating tablet by superdisintegrantaddition method. International journal of universal pharmacy and biosciences. 2013; 2(3): 425-437.

Sreenivas SA, Dandagi PM. Orodispersible tablets: Newfangled drug delivery system-A review. Indian $J$ Pharm Educ Res. 2005;39(4):177-81.

Bansod YD, Shirsat AE. Quality by Design approach to the development of Verapamil Hydrochloride floating matrix tablet. Am J Pharm Tech res. 2014; 4: 890-904.

\section{How to cite this article:}

Bhargav E, Reddy CS, Jyothi MV, Srikanth T, Sravani S, Krishna MS, Silpa T, Murali KG, Rani AS. Formulation and Optimization of Dicyclomine $\mathrm{HCl}$ mouth melt tablets by central composite design. J App Pharm Sci, 2017; 7 (09): 134-141. 